\title{
MARCION AND NEW TESTAMENT CANON
}

\author{
Liu Wisda
}

\begin{abstract}
Marcion, the bishop in the early church (85-160 AD), who was acclaimed as heretic by orthodoxy, was well-known as having the collection of a number of New Testament books. By some scholars, Marcion was regarded as the first maker of the New Testament canon, because he was the first person who publicly presented it, viz. the Gospel of Luke and ten Epistles of Paul. This article attempts to argue vice versa, by analyzing the text and context of Marcion's writings and his contemporaries.
\end{abstract}

Keywords: Marcion, New Testament literature, Canonization, Canon, Early Church Fathers, Ortodoxy

\begin{abstract}
Abstraksi: Marsion, seorang uskup dalam gereja mula-mula (85$160 \mathrm{M}$ ), yang dianggap sesat oleh ortodoksi saat itu, dikenal memiliki kumpulan atau koleksi sejumlah kitab Perjanjian Baru. Oleh sejumlah ahli, Marsion dianggap penemu atau pembuat kanon Kristen pertama karena dia dianggap orang pertama yang mempublikasikan kanon Perjanjian Baru versinya, yaitu Injil Lukas dan sepuluh surat Paulus. Artikel ini berargumentasi sebaliknya, dengan menganalisa teks dan konteks dari tulisan Marcion dan orang-orang yang hidup se-zamannya.
\end{abstract}

Kata-kata Kunci: Marsion, Literatur Perjanjian Baru, Kanonisasi, Kanon, Bapa Gereja Mula-mula, Ortodoksi 


\section{INTRODUCTION}

Gamble rightly remarks that the New Testament canon history could only be traced from sparse and fragmentary evidence, since we lack of historical evidence of how and when the New Testament canon was formed ${ }^{1}$, including data about Marcion, which is not an easy task. In particular, the issue is that Marcion's canon version containing a shorter Luke and ten Epistles of Paul has been enigmatic regarding its influence within the history of the New Testament canon over the years. Some scholars ${ }^{2}$ claim that Marcion was the first person who actualized the New Testament canon since he was the first one who publicly made known to us a selected collection of the New Testament books according to his theology. In other words, Marcion's canon is assumed as the first New Testament one.

However, regarding the position of Marcion's canon toward the history of the New Testament canon, this paper attempts to argue that Marcion was not the first maker of the New Testament canon, ${ }^{3}$ by analyzing the text and context of Marcion's and early church fathers' writings.

\footnotetext{
${ }^{1}$ Harry Y. Gamble, The New Testament Canon: Its Making and Meaning (Eugene, OR: Wipf and Stock Publisher, 2002), 23.

${ }^{2}$ Adolf von Harnack, Marcion: The Gospel of the Alien God, trans. John E. Steely and Lyle D. Bierma (Labyrinth Press, 1990); Hans von Campenhausen, The Formation of the Christian Bible (London: A. and C. Black, 1972); R.J. Hoffman, On the Restitution of Christianity (Chico., Calif.: Scholar Press, 1984); W. Kinzig, "Kaine Diatheke: The Title of the New Testament in the Second and Third Centuries", JTS 45 (1994): 519-44; J. D. BeDuhn, The First New Testament: Marcion's Scriptural Canon (Salem: Polebridge, 2013); see also H.Y. Gamble, "The New Testament Canon: Recent Research and the Status Quaestionis" in The Canon Debate, ed. Lee Martin McDonald and J.A. Sanders (Peabody, MS: Hendrickson Publishers, 2002), 292.

${ }^{3}$ The supporters of this view are Bruce Metzger, D. L. Balás, A.M. Ritter, U. Schnelle, A. F.J. Klijn; see Gamble, The New Testament Canon, 292.
} 


\section{The Definition "Canon"}

They who embrace the view that Marcion indeed is the first maker of New Testament canon base their argument from the definition of the canon as authoritative collection of books. It signifies that the collection is authoritative in some selected number of books which is determined by the church. ${ }^{4}$ As Ulrich presents that canon is "the definitive, closed list of the books that constitute the authentic contents of scripture." 5 Accordingly, the collection gained its canonical status in the fourth century, when Athanasius explicitly published the list of authoritative books. Based on this definition, BeDuhn argues that Marcion is the first maker of NT canon for two reasons: "(1) it [Marcion's New Testament] contained a fixed number of books, and (2) it was put forward in place of the Jewish scriptures, as equivalently scriptural." If we use that definition, Marcion indeed was the first maker of the New Testament canon. In other word, he was the first who limited and selected some texts as authoritative in the sense of the authoritative collection of books to support his theology. ${ }^{7}$

However, this definition is not accurate, since the term "canon" is anachronistically used by modern scholars. ${ }^{8}$ In the past, this term was not used as authoritative collection of books. The word "canon" derived from Greek means "measuring stick" and its expands to be mean "rule" or "standard." 9 From the use of the

\footnotetext{
${ }^{4}$ Metzger, The New Testament Canon, 283.

5 Eugene Ulrich, “Canon", in The Canon Debate, ed. Lee Martin McDonald and J.A. Sanders (Peabody, MS: Hendrickson Publishers, 2002), 34.

6 Jason D. BeDuhn, The First New Testament: Marcion's Scriptural Canon (Salem, OR: Polebridge Press, 2013), 26.

7 Sebastian Moll, "The Arch-Heretic Marcion", 147-148.

${ }^{8}$ John Barton, "Marcion Revisited" in The Canon Debate, ed. Lee Martin

McDonald and J.A. Sanders (Peabody, MS: Hendrickson Publishers, 2002), 344.

${ }^{9}$ See James A. Sanders, "Canon", in The Anchor Bible Dictionary, ed. David Noel Freedman, Vol. 1 (New York: Doubleday, 1996, (C) 1992), 837.
} 
word "canon" by church fathers, ${ }^{10}$ it refers to "the [church's] rule of faith that defined orthodox Christianity." 11 In particular, there are some books which are authoritatively read in the public worship of the faith community as the boundary or the rule of the Christianity. ${ }^{12}$ As Metzger explains, this implies that the authority of the books lays on their nature and source prior to their fixed collection, ${ }^{13}$ and the books can be canonical before the closed list of authoritative book was fixed in the fourth century. In other words, "canon" can be understood in the sense of the growing collection of authoritative books. ${ }^{14}$ The growing collection involves the gradual process of canonization, which is a long process of collecting, sifting, and rejecting until reaching its final list of authoritative books. ${ }^{15}$ It implies that the New Testament canon contains the element of the canon process of the New Testament which had started in early Christianity in the second century, as it grew spontaneously from the inner life of Christianity. ${ }^{16}$ As the result, it is more probable to define the canon as the growing collection of authoritative books. Accordingly, texts of the New Testament had been regarded as authoritative by Christians before the time of Marcion, implying that Marcion was not the first one who regarded some texts as authoritative.

\footnotetext{
${ }^{10}$ Church fathers like Irenaeus, Clement of Alexandria, Eusebius have similar sense of the canon term, even Tertullian explicitly uses this term for the fundamental belief which is equal to the Scriptures; see Metzger, The Canon, 158.

${ }^{11}$ McDonald and Sanders, The Canon Debate, 12; Sanders," Canon”, 837.

12 Sanders, "Canon", 837.

${ }^{13}$ Metzger, The Canon, 283.

${ }^{14}$ Ulrich, "Canon", 30.

${ }^{15}$ Metzger, The Canon, 7.

${ }^{16}$ Gamble points out the presumable overview of the process: (1) the four gospels, Paul's letters, 1 Peter and 1 John had been circulated and been used throughout Christian regions by the end of the second century, (2) the process of canonization was ongoing for the rest of New Testament books until the fourth century when they were used alongside with the previous lists, and (3) the boundary of the collection of authoritative books was delimited in the fourth and fifth centuries; see Gamble," Recent Research”, 271.
} 


\section{External Evidence}

In the light of the definition of the canon as the collection of authoritative books, there are some church fathers who regarded some New Testament texts as authoritative as well as the Old text as their Scriptures before the time of Marcion's writing (c.144 CE). Ignatius of Antioch (107 CE), a friend of Polycarp who is John's disciple, regards the word "Gospel" in equal position with the Old Testament. For example, in his letter to his former hosts in Smyrna, he says: "[...] and they have not been persuaded by the prophecies nor by the law of Moses, nay nor even to this very hour by the Gospel, nor by the sufferings of each of us severally;" ${ }^{17}$ Besides, in other writings, Ignatius utilizes the word "Gospel” interchangeably with the prophets' writing or apostles or archives or the Law of Moses or the prophecies, which implies that Ignatius' use of the word "Gospel" is attributed to the scriptural book either in one or more written book in number. ${ }^{18}$ Hill presents Ignatius' use of the term "Gospel":

Phld. 5. 1-2: gospel...apostle...prophets...gospel...gospel

Phld. 8.2: archives...gospel

Phld. 9. 1-2: prophets...apostle...gospel...gospel...

Smyrn. 5.1: the prophecies... the Law of Moses... the gospel

Smyrn. 7. 2: prophets... gospel ${ }^{19}$

These show five categories: gospel, apostle, prophets or prophecies, archives, and the Law of Moses which used to design the OT scriptures (the Laws of Moses, prophets) and portions of NT (the gospel, apostle). The question is that does Ignatius refer

\footnotetext{
${ }^{17}$ Ignatius, Smyrneans 5:1.1, translated by J.B. Lightfoot and Harmer, edition 1891, accessed October 17, 2017, http://www.earlychristianwritings.com/text/ignatius-smyrnaeans-lightfoot.html. 18 Hill, "Ignatius", 269.

${ }^{19}$ Hill, "Ignatius", 269.
} 
the gospel to the written text? In one of his writings on Philadelphian 8.2, he says:

and I exhort you to do nothing of contention, but according to the discipline of Christ. Since I have heard certain men say, "Unless I find it in the archives, I believe it not in the Gospel." And when I said unto them that "It is written," they replied, "That it just the question." But my archives are Jesus Christ; his cross and his death, his resurrection, and the faith which is through him, are inviolable archives, through which I desire to be justified by means of your prayers. $^{20}$

In this passage, Ignatius was arguing with some Philadelphian Christians who did not accept his particular understanding of the Gospel except they found it from archives. ${ }^{21}$ The archives and Ignatius's use of "it is written" here are acknowledged to refer to the Old Testament as the written document. $^{22}$ Answering their question, Ignatius, might be difficult to establish his point of archives in countering the Philadelphian, appealed the higher authority of Christ himself, his cross, death and resurrection as the ultimate archives, which probably contained in the Gospel as his source ${ }^{23}$ since he mentions the Gospel in Phld. 5.1 alongside 9.1-2 interchangeably with Jesus Christ. In other

\footnotetext{
${ }^{20}$ Ignatius, Philadelphian 8.2. translated by Charles H. Hoole, accessed November 9, 2017, http://www.earlychristianwritings.com/text/ignatiusphiladelphians-hoole.html. The italic is Hill's translation. See Hill, "Ignatius," 271.

${ }^{21}$ Hill, "Ignatius", 271

${ }^{22}$ Hill, "Ignatius", 270, 272. From the context of Ignatius' discussion with Philadelphians in Phld. 5.2; 8.2; 9.1-2 and Smyrn. 7.1, Philadelphians seemed to be Christian Judaizers which emphasized much on the OT scripture, and Ignatius seemed to have known little about it; so "the archives" here is the OT scripture; see W.R. Schoedel, "Ignatius and the Archives," HTR 71 (1978): 97-106.

${ }^{23}$ Hill, "Ignatius", 273.
} 
words, because "the word "the Gospel" here "appears in opposite reference to the OT scripture and in the context of comparison of written religious authorities," 24 it demonstrates that Ignatius has the strong sense of the written Gospel. As Hill points out that "because the archives are written document of religious authority, the Old Testament, it is possible to read 'the gospel' as a reference to a written authority." 25 Accordingly, Ignatius treats "the archives" (the written OT texts) in same way with the written Gospel in countering Philadelphian's objection.

In addition, the anonymous homily of 2 Clement (100-140 $\mathrm{CE})$ as the first non-canonical writing mentions the Gospel passage as Scripture: "Again another scripture saith, I came not to call the righteous, but sinners" (2 Clement 2:4), ${ }^{26}$ which is parallel to Mark 2:17, and Matthew 9:13. The writer here regards Jesus' saying as Scripture, which has the same scriptural category with the Old Testament text, in which he quotes Ezekiel: "And the scripture also saith in Ezekiel, Though Noah and Job and Daniel should rise up, they shall not deliver their children in the captivity" (2 Clem 6:8). Jesus' saying which he appeals somehow is the written document, as the writer says, "For the Lord saith in the Gospel, if ye kept not that which is little, who shall give unto you that which is great? For I say unto you that he which is faithful in the least, is also faithful in much" (2 Clem 8:5). In other words, the phrase "the Lord saith in the Gospel" here shows a strong sense of written Gospel since the "preacher tells his "brothers and sisters" that he is reading them a "petition" or "plea" to "pay attention to what is written", i.e. to

\footnotetext{
${ }^{24}$ Hill, "Ignatius", 273.

25 Hill, "Ignatius", 273.

${ }^{26} 2$ Clement 2:4, transl. J.B. Lightfoot, accessed November 9, 2017 , http://www.earlychristianwritings.com/text/2clement-lightfoot.html.
} 
the scriptures which he frequently cites." 27 This implies that the writer of 2 Clement treats the written Gospel in same place with the written the OT scripture when he cites them in his sermon. Therefore, in some sense the preacher acknowledges the NT text as the written Scripture which equals to the OT text as authoritative.

Furthermore, the codex format in the sense that there were bound collections of early several manuscripts in all likelihood is the other evidence of the early NT canon due to its convenience for Christian scribes who were traveling for mission or distribution or other purposes, and its practice to be read in the public worship. ${ }^{28}$ $\mathfrak{P}^{46}$ is one of the examples of the codex (c. $200 \mathrm{CE}$ ) containing ten Epistles of Paul without the three Pastoral Epistles. ${ }^{29}$ Other fragmentary manuscripts, like $\mathfrak{P}^{52}$ (John 18:31-33, 37-38) and $\mathfrak{P}^{90}$ (John 18:36-19:1; 19:2-7) $\mathfrak{P}^{64}$ and $\mathfrak{P}^{66}$, are dated at around $200 \mathrm{CE}$ which seem coming from codices although they do not contain all the collection of the New Testament text. ${ }^{30}$ From these pieces of evidence, Balla's analysis shows that the manuscripts were copied repeatedly and the order of the earliest manuscripts was not fixed, therefore, the process of canonization was at work until reached its

272 Clement 19:1; Robert M. Grant, "Second Epistle of Clement," in The Anchor Bible Dictionary, Vol. 1, ed. David Noel Freedman (New York: Doubleday, 1996, c1992), 1061.

${ }^{28}$ Peter Balla, "Evidence for an Early Christian Canon (Second and Third Century)" in The Canon Debate, ed. Lee Martin McDonald and J.A. Sanders (Peabody, MS: Hendrickson Publishers, 2002), 376; Stanton, Jesus, 84. Stanton mentions the interesting fact of the codex usage: "among non-Christian papyri, rolls predominate until early in the fourth century, but Christian papyri are very nearly all fragments of codices. With only one possible exception, every single papyrus copy of the gospels is from a codex." This is because the codex is a kind of an intentional distinctive expression of Christianity from both Judaism and pagan world. See Stanton, Jesus, 82.

${ }_{29}$ Metzger, The Canon, 54; Balla," Canon", 377.

${ }^{30}$ Balla, "Canon", 376-377. See the lists of papyri at the appendix I in NestleAland, Novum Testamentum $28^{\text {th }}$ Revised Edition (Stuttgart, Germany: Deutsche Bibelgesellschaft, 2012), 792-799. 
fixed order at the fourth century. ${ }^{31}$ Stanton also notes that that Chester Beatty papyri, including $\mathfrak{P}^{46}$ confirms the use of the codex in the second century. ${ }^{32}$ These fragmentary codices which are known to us already been in the collection of New Testament texts, implying other codices which already lost or damaged prior to the time of $\mathfrak{P}^{46}$ might have the same format due to the circulation of New Testament texts by Christians throughout places. In addition, the author of 2 Peter $^{33}$ provides evidence that at the time, the use of the collection of authoritative books was familiar with the writer, especially Paul's writings. 2 Peter 3: 15-16 says:

Bear in mind that our Lord's patience means salvation, just as our dear brother Paul also wrote you with the wisdom that God gave him. He writes the same way in all his letters, speaking in them of these matters. His letters contain some things that are hard to understand, which ignorant and unstable people distort, as they do the other Scriptures, to their own destruction. (NIV)

These two verses show the author's knowledge about a number of Paul's letters, implying that the author had some acquaintance with the collection of Paul's writings. This gives us the evidence of the earlier usage of the collection of Pauline epistles which has been widespread and was known by Christians. Therefore, since the development of the canon of the New Testament as early as there were earliest church fathers treated some New Testaments as authoritative and read in the Christian worship, and some pieces of manuscript evidence shows the

\footnotetext{
${ }^{31}$ Balla, "Canon", 377.

32 Stanton, "Jesus", 166.

${ }^{33}$ Although the dating of the letter of 2 Peter is still disputed, most scholars agree that its dating is the first decades of the second century. See Karl P. Donfried, "Peter", in The Anchor Bible Dictionary, Vol. 5, ed. David Noel Freedman (New York: Doubleday, 1996, c1992), 262.
} 
familiar usage of collection books, it is more probable that "Marcion was surely not the first Christian to consider certain [New Testament] texts as authoritative."34

\section{Internal Evidence}

Marcion's works (his Euangelion and Apostolikon) shows that he was rather conservative than innovative toward the New Testament text, implying that he followed the Scriptures which already were present at that time, and he did not create a new Gospel. $^{35}$ Based on Moll's comprehensive study on Marcion' works, he notes that Marcion did not change or add something new to his canonical version, but he cut off all New Testament passages relating to the Old Testament which were not in accord with his doctrine. ${ }^{36}$ Tertullian states that "Marcion expressly and openly used the knife, not the pen, since he made such an excision of the Scriptures as suited his own subject-matter."37 For example, he deleted Luke 1:1-4:15 without adding new tenet on his version of Gospel of Luke, as the deleted texts have association with the Old Testament God who he rejected. ${ }^{38}$ In addition, Robert M. Grant presents that "in Luke 10:21. "I thank thee, Lord of heaven"[Marcion omits] both "Father" and "of earth," but continuing with "Yea, Father." This is attested by Tertullian (4.25.1). Similarly, Marcion retains Luke 11:5-13 but has it end "how much more the

\footnotetext{
${ }^{34}$ Sebastian Moll, "At the Left Hand of Christ: The Arch-Heretic Marcion" (PhD diss., The University of Edinburgh), 147.

${ }^{35}$ Moll, "The Arch-Heretic Marcion", 178.

${ }^{36}$ Moll, "The Arch-Heretic Marcion", 224.

${ }^{37}$ Tertullian, The Prescription Against Heretics, 38, The Ante-Nicene Fathers

Vol. III: Translations of the Writings of the Fathers Down to A.D. 325, Latin

Christianity: Its Founder, Tertullian. transl. Peter Holmes, ed. Alexander

Roberts, James Donaldson and A. Cleveland Coxe (Oak Harbor: Logos Research Systems, 1997), 262.

${ }^{38}$ Moll, "The Arch-Heretic Marcion", 131-2.
} 
Father?" (deleting "from heaven")."39 Likewise, Marcion omitted Luke 8:19; 9:31 and 13:1-9. ${ }^{40}$ He also deletes some texts Paul's writing which are regarded as having Judaizing interpolations, for instances, Gal. 3:16-4:6; 2 Thess. 1:6-8. These examples show that Marcion cut off some texts in order to adjust to his doctrine. Therefore, it is hard to say that Marcion was the innovator of the New Testament texts here since "he did not create the new category of Christian scripture" 41 by excising some texts, or to use Hurtado words, Marcion did not compose his own gospels, apocalypses, acts, or epistles or other extracanonical writings. ${ }^{42}$

In addition, he was conservative because he did not emend the Old Testament text, although he excluded it from his canon. This is because "Marcion did not understand the Old Testament in the light of the New, he interpreted the New Testament in the light of the Old." 43 His canon was based on his theological emphasis, which is the discontinuity between the Old Testament and the New. ${ }^{44}$ He rejects the Old Testament and differentiates the good God of Creator, who is Jesus as the Supreme God, and the evil God of Jews. ${ }^{45}$ Irenaeus explains:

\footnotetext{
${ }^{39}$ Robert M. Grant, "Gospel of Marcion", in The Anchor Bible Dictionary, Vol. 4, ed. David Noel Freedman, (New York: Doubleday, 1996, c1992), 517.

${ }^{40}$ Moll, "The Arch-Heretic Marcion", 134-135.

${ }^{41}$ Barton, "Marcion Revisited", 347.

${ }^{42}$ Hurtado, Lord Jesus Christ: Devotion to Jesus in Earliest Christianity (Grand Rapids, MI: W. B. Eerdmans Publishing Co., 2003), 552.

${ }^{43}$ Moll, "The Arch-Heretic Marcion", 118.

${ }^{44}$ Moll, "Arch-Heretic Marcion", 111.

45 Bruce Metzger, The Canon of the New Testament (New York, NY: Oxford University Press, 1987), 91. Irenaeus informs that Marcion's teaching is influenced by Cerdo, a Syrian Gnostic (Against Heresies, I. 27. 1-3), taken from Metzger, The Canon, 91. Irenaeus's information was followed by latter fathers: Tertullian, Adv. Marc. 1.2, 22; III.21; IV.17; Hippolytus/Re/uf. 10.15; Eusebius, Hist. Eccl. IV.10.
} 
[...] indeed, the followers of Marcion do directly blaspheme the Creator, alleging him to be the creator of evils, [but] holding a more tolerable theory as to his origin, [and] maintaining that there are two beings, gods by nature, differing from each other, -the one being good, but the other evil. Those from Valentinus, however, while they employ names of a more honorable kind, and set forth that He who is Creator is both Father, and Lord, and God, do [nevertheless] render their theory or sect more blasphemous, by maintaining that $\mathrm{He}$ was not produced from any one of those Aeons within the Pleroma, but from that defect which had been expelled beyond the Pleroma. Ignorance of the Scriptures and of the dispensation of God has brought all these things upon them. ${ }^{46}$

One part of his teaching is that Christ in the New Testament sets believers free from Law, while Moses in the Old Testament commands Jews to obey the Law. ${ }^{47} \mathrm{He}$ also describes the Old Testament God: the evil God, Creator, God of Jews, Lawgiver, Judge, unworthy of a God, the Creator's Messiah, and considers the NT God is good who is revealed in Jesus Christ and preached by the Apostle Paul. ${ }^{48}$ Tertullian points out:

Since, therefore, it is this very opposition between the law and the gospel which has suggested that the God of the gospel is different from the God of the law, it is clear that, before the said separation, that god could not have been known who became known from the argument of the separation itself. He therefore could not have been revealed by Christ, who came before the separation, but must have been devised by Marcion, the author of the breach of peace between the gospel and the law. Now this peace, which had

\footnotetext{
${ }^{46}$ Irenaeus, Against Heresies, III.12, 12. Peter Kirby, "Irenaeus of Lions," Early Christian Writings, accessed October 16, 2017, http://www.earlychristianwritings.com/text/irenaeus-book3.html ${ }^{47}$ Mezger, The Canon, 92.

${ }^{48}$ Moll, "The Arch-Heretic Marcion", 86-93.
} 
remained unhurt and unshaken from Christ's appearance to the time of Marcion's audacious doctrine, was no doubt maintained by that way of thinking, which firmly held that the God of both law and gospel was none other than the Creator, against whom after so long a time a separation has been introduced by the heretic of Pontus. ${ }^{49}$

To summarize Marcion's doctrine, there are five rules of Marcion's bible: 1) The tradition of the Church is falsified; 2) Christ is not the Son of the Old Testament God; 3) Christ is neither born nor raised; 4) The Old Testament or its figures are no authority for Christ; and 5) The Old Testament cannot be fulfilled in Christ. ${ }^{50}$

Although he rejected the God of the Old Testament, it does not mean that he regarded the Old Testament as false. ${ }^{51}$ Barton states that Marcion still considered the Old Testament as the revelation from an evil deity, which shows that Marcion is a traditionalist but radical than his contemporary Christians. ${ }^{52}$ However, since he rejected the evil God of the Old Testament, he deleted all the Old texts and some New Testament texts which associated with the God of Old Testament from his canon, so it only contained the short version of Gospel of Luke and ten epistles of Paul. Thus, this shows that he did not create a new canon, as he was conservative to the Old and New Testament text in the sense that his canon was made according to the known pattern which have been widespread in the second-century church." ${ }^{, 53}$

\footnotetext{
49 Tertullian, The Five Books Against Marcion, I. 19, transl. Holmes, accessed November 2017, http://www.earlychristianwritings.com/text/tertullian121.html. ${ }^{50}$ This is Moll's guidelines of the way Marcion interprets the NT from his OT theology; see the explanation in Moll, "The Arch-Heretic Marcion", 131-139.

51 Barton, "Marcion Revisited", 347.

52 Barton, "Marcion Revisited", 347.

${ }^{53}$ Barton, "Marcion Revisited", 354.
} 


\section{CONCLUSION}

Taking these pieces of evidence into account, we can conclude that Marcion was not the first maker of the New Testament canon. Clarifying the definition of the canon itself makes sense the context. If the authoritative collection of books is taken for granted as the meaning of the canon, then Marcion was the first person who creates the New Testament canon. As the canon is inherent in the sense that it naturally and spontaneously arose from Christianity, canon must be defined as the collection of authoritative books in terms of the growing collection. Accordingly, the nature of the canon involves the process of canonization of the New Testament early as the second century, where some earliest church fathers before Marcion's time appealed some New Testament texts and regarded them equal with the Old as Christian scriptures, such as Ignatius (c. $107 \mathrm{CE}$ ), the author of 2 Peter, and 2 Clement. Moreover, the usage of earliest codex format, though is fragmentary, it can also be another piece of evidence of collection of authoritative writings used in the liturgical life of the church. Likewise, the fact that the orthodox church did not make a countering canon in response to Marcion's canon gives us a hint that Marcion's canon was not something new to the church as the NT canon had already started earlier than Marcion's time. These data show that although Marcion was the first who clearly gave the list of scripture of his version, prior to his time, there were some collection of books regarded by some church fathers as authoritative. In short, Marcion was not the first creator of New Testament canon. 


\section{BIBLIOGRAPHY}

Balla, Peter. "Evidence for an Early Christian Canon (Second and Third Century)." In the Canon Debate. Edited by Lee Martin McDonald and J. A. Sanders. Peabody, MS: Hendrickson Publishers, 2002.

Barton, John. "Marcion Revisited" in The Canon Debate. Edited by Lee Martin Mc Donald and J. A. Sanders. Peabody, MS: Hendrickson Publishers, 2002.

BeDuhn, Jason D. The First New Testament: Marcion's Scriptural Canon. Salem, OR: Polebridge Press, 2013.

Donfried, Karl P. "Peter." In the Anchor Bible Dictionary, Vol. 5. Edited by David Noel Freedman. New York: Doubleday, 1996, c1992

Gamble, Harry Y. The New Testament Canon: Its Making and Meaning. Eugene, OR: Wipf and Stock Publisher, 2002.

Gamble, Harry Y. "The New Testament Canon: Recent Research and the Status Questionis." In the Canon Debate. Edited by Lee Martin Mc Donald and J. A. Sanders. Peabody, MS: Hendrickson Publishers, 2002.

Grant, Robert M. "Gospel of Marcion", in the Anchor Bible Dictionary, Vol. 4. Edited by David Noel Freedman. New York: Doubleday, 1996, (C) 1992.

Grant, Robert M. "Second Epistle of Clement", in the Anchor Bible Dictionary, Vol. 1. Edited by David Noel Freedman. New York: Doubleday, 1996, (c) 1992.

Hill, Charles E. "Ignatius, 'the Gospel,' and the Gospels", in Trajectories through the New Testament and the Apostolic Fathers. Edited by Andrew Gregory and Christopher Tuckett. New York, NY: Oxford University Press, 2005. 
Hoffman, R. J. On the Restitution of Christianity. Chico., Calif.: Scholar Press, 1984.

Hurtado, Larry. Lord Jesus Christ: Devotion to Jesus in Earliest Christianity. Grand Rapids, MI: William B. Eerdmans Publishing Co., 2003.

Ignatius, Smyrneans. Translated by J. B. Lightfoot and Harmer, edition 1891. Accessed October 17, 2017. Http://www.earlychristianwritings.com/text/ignatiussmyrnaeans-lightfoot.html.

Kinzig, W. "Kaine Diatheke: The Title of the New Testament in the Second and Third Centuries", in JTS 45 (1994): 519-44.

May, Jordan Daniel. "The Four Pillars: The Fourfold Gospel Before the Time of Irenaeus", in Trinity Journal $30 \mathrm{NS}$ (2009): 67-79.

Metzger, Bruce. The Canon of the New Testament. New York, NY: Oxford University Press, 1987.

Sanders, James A. "Canon", in the Anchor Bible Dictionary. Edited by David Noel Freedman. Volume 1. New York: Doubleday, 1996, (C) 1992.

Sebastian Moll, "At the Left Hand of Christ: The Arch-Heretic Marcion.” Ph.D diss., The University of Edinburgh, 2009.

Stanton, Graham. Jesus and Gospel. UK: Cambridge University Press, 2004.

Tertullian, The Prescription Against Heretics, 38. In the AnteNicene Fathers Vol. III: Translations of the Writings of the Fathers Down to A.D. 325, Latin Christianity: Its Founder, Tertullian. Translated by Peter Holmes, ed. Alexander Roberts, James Donaldson and A. Cleveland Coxe. Oak Harbor: Logos Research Systems, 1997. 
von Harnack, Adolf. Marcion: The Gospel of the Alien God. Translated by John E. Steely and Lyle D. Bierma. Labyrinth Press, 1990.

von Campenhausen, Hans. The Formation of the Christian Bible. London : A. and C. Black, 1972. 